\title{
STRATEGI PENINGKATAN KUALITAS LAPORAN KEUANGAN PEMERINTAH KABUPATEN KEPULAUAN ANAMBAS
}

\section{Strategy on the Improvement of Quality of Financial Report of Kepulauan Anambas Regency Government}

\author{
Herryanto1, Ma`mun Sarma², Abdul Kohar Irwanto² \\ ${ }^{1}$ Staf Badan Kepegawaian dan Pengembangan Sumber Daya Manusia, Kab Kep Anambas, Provinsi \\ Kepulauan Riau. E-mail : akunhery@gmail.com \\ 2Staff Pengajar Departemen Manajemen, Fakultas Ekonomi dan Manajemen. IPB. E-mail : \\ mamun_sarma@yahoo.com_irwanto.abdulkohar@yahoo.com
}

\begin{abstract}
In advance of the society demand due to implementation of Good Governance, it has encouraged local government to deliver an accountabiliy of reasonable and qualified finance statement reports. This research aimed to analyze the finance official persepsion's towards the variable of the human resources competency in finance managerial, internal government control application system and local financial information system, to analyze the elements which become strenghts and weaknesses and to formularize the priority strategic in order to enhance the quality of financial statement reports in local government of Anambas Islands Regency. The type of data used in this research consist of primary data dan secondary data. The primary data were obtained by direct observation, interview and debriefing, and the questionnaire to the purposively respondents (purposive sampling) whereas the secondary data were obtained by literature review and documents research. The methods of analysis that were Rating Scale Analysis, SWOT Analysis and QSPM method. The research of study result indicates of the poor human resource competency in finance official that has become the weakness of enhancement of quality financial statement reports. The chosen of primary priority strategy that adequate and capable to be implemented is to enhance the quality of human resources in finance managerial of local government in order to establish financial statement reports.
\end{abstract}

Key words: Strategy on the improvement of quality of financial report, regional finance, Kepulauan Anambas Regency

\section{ABSTRAK}

Meningkatnya tuntutan masyarakat terhadap penyelenggaraan pemerintahan yang baik telah mendorong pemerintah daerah menyampaikan laporan pertanggungjawaban berupa laporan keuangan yang wajar dan berkualitas. Penelitian ini bertujuan untuk : menganalisis persepsi pengelola keuangan terhadap variabel kompetensi sumber daya manusia pengelola keuangan, penerapan sistem pengendalian intern pemerintah dan sistem informasi keuangan daerah terhadap peningkatan kualitas laporan keuangan, menganalisis faktor-faktor yang menjadi kekuatan dan kelemahan dalam peningkatan kualitas laporan keuangan dan merumuskan strategi yang perlu diprioritaskan dalam peningkatan kualitas laporan keuangan pada Pemerintah Kabupaten Kepulauan Anambas. Jenis data yang akan digunakan dalam penelitian ini terdiri dari data primer dan data sekunder. Data primer diperoleh dengan cara observasi langsung, wawancara dan penyebaran kuesioner kepada responden yang dipilih secara sengaja (purposive sampling). Sedangkan untuk mendapatkan data sekunder berasal dari studi pustaka dan kajian terhadap dokumen terkait. Metode analisis yang digunakan adalah analisis rating scale, analisis SWOT dan metode QSPM. Hasil penelitian menunjukkan bahwa lemahnya kompetensi aparatur pengelola keuangan menjadi kelemahan dalam peningkatan kualitas laporan keuangan. Strategi prioritas utama yang terpilih dan dapat diimplementasikan adalah meningkatkan kualitas SDM pengelola keuangan daerah dalam penyusunan laporan keuangan.

Kata kunci : Strategi Peningkatan Kualitas Laporan Keuangan, Keuangan Daerah, Kabupaten 


\section{PENDAHULUAN}

Seiring dengan meningkatnya
tuntutan penyelenggaraan pemerintahan yang baik (good governance goverment) telah mendorong pemerintah pusat maupun pemerintah daerah untuk menerapkan akuntabilitas publik salah satunya melalui pelaporan keuangan yang wajar dan berkualitas. Pemerintah daerah akan mampu mewujudkan transparansi dan akuntabilitas dalam pengelolaan keuangan daerah apabila informasi yang terdapat di dalam Laporan Keuangan Pemerintah Daerah (LKPD) memenuhi kriteria karakteristik kualitatif laporan keuangan pemerintah seperti yang disyaratkan dalam Peraturan Pemerintah Nomor 71 Tahun 2010. Karakteristik kualitatif laporan keuangan pemerintah daerah merupakan syarat normatif yang diperlukan agar laporan keuangan pemerintah dapat memenuhi kualitas yang dikehendaki, yaitu : relevan, andal, dapat dibandingkan dan dapat dipahami. LKPD setiap tahunnya mendapat penilaian berupa opini dari Badan Pengawas Keuangan (BPK). Ketika BPK memberikan opini Wajar Tanpa Pengecualian (WTP) terhadap LKPD artinya dapat dikatakan bahwa laporan keuangan pemerintah daerah tersebut disajikan dan diungkapkan secara wajar dan berkualitas. Terdapat empat opini yang diberikan pemeriksa yaitu : opini Wajar Tanpa Pengecualian (WTP), opini Wajar Dengan Pengecualian (WDP), opini Tidak Wajar (TW), dan Pernyataan Menolak Memberi Opini atau Tidak Memberi Pendapat (TMP).

Permasalahan laporan keuangan Pemerintah Kabupaten Kepulauan Anambas merupakan hal yang sangat menarik untuk dikaji lebih lanjut. Hal ini dikarenakan berdasarkan hasil pemeriksaan BPK dalam rentang waktu tahun 2008 sampai tahun 2014, LKPD Kabupaten Kepulauan Anambas pernah berada pada posisi opini terendah (disclaimer) hingga opini prestisius (unqualified). Pada tahun 2008, BPK pernah memberikan opini Tidak Memberikan Pendapat (TMP) atau disclaimer terhadap LKPD Kabupaten Kepulauan Anambas dan 4 tahun berturutturut hanya meraih Wajar Dengan Pengecualian (WDP). Terakhir, pada tahun 2015, laporan keuangan Pemerintah Kabupaten Kepulauan Anambas meraih opini Wajar Tanpa Pengecualian (WTP) dari BPK RI (BPKRI,2015).

Predikat Wajar Tanpa Pengecualian (WTP) untuk tahun anggaran 2015 yang didapat oleh Pemkab Anambas atas Laporan Hasil Pemeriksaan Keuangan (LHP) BPK RI Perwakilan Provinsi Kepri merupakan lompatan besar, mengingat hasil pemeriksaan BPK RI terhadap laporan keuangan tahun anggaran 2008 adalah tidak menyatakan pendapat (disclaimer) yang merupakan predikat terendah hasil pemeriksaan keuangan yang disandang oleh suatu daerah dan hanya mendapat predikat wajar dengan pengecualian pada tahun-tahun berikutnya. Opini disclaimer untuk LHP tahun 2008 yang diberikan BPK RI atas LHP Pemkab Anambas disebabkan karena ketidaksesuaian penyajian dengan Standar Akuntansi Pemerintah (SAP), kelemahan pengendalian intern, ketidakpatuhan terhadap ketentuan perundang-undangan serta ketidakcukupan pengungkapan laporan keuangan. Motivasi-motivasi tersebut menjadi topik yang menarik untuk diteliti, sehingga perlu diketahui faktor kelemahan dan kekuatan dalam pengelolaan keuangan daerah pada Pemerintah Kabupaten Kepulauan Anambas dalam upaya mempertahankan opini WTP yang telah diraih.

Tujuan dari penelitian ini adalah : (1) Menganalisis persepsi pengelola keuangan terhadap variabel kompetensi SDM, penerapan sistem pengendalian intern pemerintah, dan sistem informasi keuangan daerah terhadap peningkatan kualitas laporan keuangan Pemerintah Kabupaten Kepulauan Anambas; (2) 
Menganalisis faktor-faktor yang menjadi kekuatan dan kelemahan dalam peningkatan kualitas laporan keuangan di Kabupaten Kepulauan Anambas dan (3) Merumuskan strategi yang perlu diprioritaskan dalam peningkatan kualitas laporan keuangan pada Pemerintah Kabupaten Kepulauan Anambas.

\section{METODE PENELITIAN}

Penelitian dilakukan di Kabupaten Kepulauan Anambas Provinsi Kepulauan Riau tepatnya pada Badan Keuangan Daerah (BKD). Badan Keuangan Daerah merupakan Satuan Kerja Pengelola Keuangan Daerah yang melaksanakan pengelolaan keuangan daerah di Kabupaten Kepulauan Anambas. Jenis data yang digunakan dalam penelitian ini terdiri dari data primer dan data sekunder. Data primer diperoleh dengan cara observasi langsung, wawancara dan penyebaran kuesioner. Sedangkan untuk mendapatkan data sekunder berasal dari studi pustaka dan kajian terhadap literatur terkait. Responden terdiri dari Pejabat Penatausahaan Keuangan Daerah (PPKSKPD) dan pimpinan Badan Keuangan Daerah yang berhubungan langsung dan bertanggung jawab terhadap pengelolaan keuangan di Kabupaten Kepulauan Anambas dan dipilih secara purposive sampling. Pemilihan responden berdasarkan pertimbangan bahwa responden merupakan pejabat yang bertugas melakukan penyusunan laporan keuangan sesuai tugas pokok dan fungsinya seperti yang tercantum dalam Peraturan Menteri Dalam Negeri Nomor 13 Tahun 2006 tentang Pedoman Pengelolaan Keuangan Daerah pasal 13 ayat 2. Data sekunder diperoleh dari Laporan Hasil Pemeriksaan Badan Pemeriksa Keuangan tahun 2011 - 2015, dokumen serta regulasi terkait dan relevan dalam penelitian ini. Alat analisis yang digunakan untuk sesuai dengan urutan tujuan dalam penelitian ini adalah: (1) Analisis ratting scale, (2) analisis SWOT serta (3) analisis Quantitative Strategic Planning Matrix (QSPM).

Analisis rating scale dilakukan untuk mengukur dan melakukan evaluasi sehingga dapat membandingkan kondisi sesungguhnya mengenai kualitas LKPD. Menurut Riduwan (2010) dalam rating scale responden akan menjawab salah satu data kuantitatif yang telah disediakan. Analisis rating scale dilakukan melalui pengisian kuesioner oleh Pejabat Penatausahaan Keuangan (PPK SKPD). Penentuan skor menggunakan skala penilaian $1-4$ terhadap seluruh faktor yang berpengaruh terhadap kualitas LKPD yang meliputi kompetensi sumberdaya manusia, sistem pengendalian intern pemerintah, dan sistem informasi keuangan daerah. Semakin tinggi skor hasil yang diperoleh maka semakin baik kondisi kualitas LKPD yang dihasilkan.

Analisis SWOT perlu dilakukan untuk menetapkan pemilihan strategi yang paling tepat dalam rangka peningkatan kualitas laporan keuangan Pemerintah Kabupaten Kepulauan Anambas. Adapun faktor penting yang menjadi tujuan dalam pemilihan strategi peningkatan kualitas laporan keuangan tersebut yaitu faktor kunci internal (IFE) dan faktor kunci eksternal (EFE). Penentuan bobot dilakukan dengan mengajukan identifikasi faktor internal dan eksternal kepada stakeholder dengan menggunakan metode paired comparison (Kinnear dan Taylor, 1991). Metode ini digunakan untuk memberikan penilaian terhadap bobot di setiap faktor-faktor internal dan eksternal.

Penggunaan analisis QSPM bertujuan untuk memperoleh prioritas strategi terbaik yang paling menarik untuk diimplementasikan sesuai dengan arah dan kebijakan Pemerintah Kabupaten Kepulauan Anambas dalam hal pengelolaan keuangan daerah. Analisis QSPM menggunakan skor daya tarik atau Atrractiveness Scores (AS) dengan Nilai Daya Tarik adalah $1=$ tidak menarik, $2=$ agak menarik, $3=$ cukup menarik, $4=$ sangat menarik. Penentuan prioritas 
strategi terbaik dilakukan dengan cara menentukan rating atau tingkat ketertarikan relatif dari strategi-strategi yang telah dipilih. Nilai Total Attractiveness Scores (TAS) tertinggi menandakan strategi yang paling layak untuk diimplementasikan dengan memperhatikan seluruh faktor internal dan eksternal.

\section{HASIL DAN PEMBAHASAN Analisis persepsi pengelola keuangan terhadap kualitas laporan keuangan Pemerintah Kabupaten Kepulauan Anambas}

Analisis persepsi pengelola keuangan terhadap kualitas laporan keuangan pada Pemerintah Kabupaten Kepulauan Anambas digunakan untuk mengukur dan melakukan evaluasi sehingga dapat membandingkan kondisi sesungguhnya mengenai kualitas LKPD.

Kompetensi SDM Pengelola Keuangan

Berdasarkan pengukuran yang dilakukan terhadap persepsi responden mengenai kompetensi SDM pengelola keuangan pada Pemerintah Kabupaten Kepulauan Anambas diperoleh skor total rata-rata keseluruhan kompetensi SDM adalah 924 dengan persentase sebesar $79,11 \%$ dari skala kriterium atau 3,16 (likert skala 4). Hasil perolehan skor menunjukkan bahwa kompetensi SDM sudah baik namun belum optimal dan masih harus dilakukan berbagai perbaikan pada indikator yang dinilai masih kurang.

Adapun berdasarkan penilaian indikator kompetensi SDM masih terdapat indikator yang kurang baik yaitu :

1. Pengetahuan

Sebagian besar responden menjawab bahwa mereka masih kurang memahami siklus akuntansi yang berlaku dikarenakan sebagian besar pengelola keuangan memiliki latar belakang pendidikan non ekonomi.

2. Keahlian

Indikator kompetensi SDM yaitu keahlian menurut persepsi sebagian besar responden pada setiap satuan kerja perangkat daerah masih kurang baik khususnya terhadap pernyataan yang terkait dengan pelatihan yang diberikan kepada pengelola keuangan. Sebagian besar responden berpendapat bahwa pelatihan peningkatan kompetensi pengelola keuangan yang dikoordinir oleh Badan Pengembangan Sumber Daya Manusia (BKPSDM) sejak terjadinya defisit anggaran sangat berkurang bahkan hampir tidak dilakukan. Berdasarkan hasil penelitian yang telah dilakukan oleh Eriva et al. (2013) membuktikan bahwa pelatihan yang dilakukan oleh suatu pemerintah daerah akan sangat mempengaruhi pemahaman pengelola keuangan suatu pemerintah daerah. Instansi pemerintah seharusnya rutin menyelenggarakan pelatihan dan pembimbingan untuk membantu pegawai mempertahankan dan meningkatkan kompetensi pekerjaannya sehingga mampu mencapai pengendalian intern yang efektif. Seseorang yang memiliki kompetensi akan bekerja dengan pengetahuan dan ketrampilannya sehingga dapat bekerja dengan mudah, cepat, intuitif dan dengan pengalamannya bisa meminimalisir kesalahan termasuk dalam hal kepatuhan terhadap peraturan perundang-undangan pengelolaan keuangan (Syarifudin, 2014).

Pernyataan ini didukung kuat oleh hasil temuan Badan Pemeriksa Keuangan pada Laporan Hasil Pemeriksaan tahun 2016 yang menyatakan bahwa masih lemahnya sistem pengendalian intern Pemerintah Kabupaten Kepulauan Anambas yang diakibatkan kurangnya pemahaman pengelola keuangan sehingga menyebabkan rendahnya kepatuhan terhadap peraturan perundang-undangan. Lemahnya sistem mutasi dan promosi mengakibatkan belum tersedianya pegawai pengelola keuangan dengan kompetensi yang memadai sebagai kader atau penggantinya. Hal ini mengakibatkan banyak pengelola keuangan kurang memahami pengelolaan keuangan daerah 
yang berakibat terhadap kualitas pelaporan keuangan pada setiap entitas akuntansi. Hal ini berkaitan erat dengan sistem pengendalian intern yang menyatakan bahwa setiap pimpinan instansi tidak boleh melakukan mutasi pegawai yang berlebihan pada fungsifungsi kunci termasuk fungsi akuntansi dan sistem pengendalian intern. Adanya perputaran pegawai yang tidak berpola menandakan lemahnya perhatian pimpinan instansi terhadap sistem pengendalian intern.

\section{Sistem Pengendalian Intern Pemerintah}

Berdasarkan hasil pengolahan data yang dilakukan menunjukkan bahwa skor total yang diperoleh dari hasil pengisian kuesioner terhadap sistem pengendalian intern pemerintah sebesar 1.660 dengan persentase sebesar $72,55 \%$ dari skala kriterium atau 2,90 (likert skala 4). Hasil perolehan skor menunjukkan bahwa sistem pengendalian intern pemerintah di Lingkungan Pemerintah Kabupaten Kepulauan Anambas masih belum sepenuhnya berjalan dengan baik. Hasil perolehan skor total berada pada interval kurang baik, namun sudah mendekati baik. Hal ini menggambarkan bahwa masih perlu dilakukan berbagai perbaikan dalam sistem pengendalian intern dalam mendukung upaya peningkatan kualitas LKPD dimasa yang akan datang.

Berdasarkan analisis terhadap sistem pengendalian intern pemerintah masih terdapat indikator yang belum berjalan dengan baik yaitu:

\section{Lingkungan Pengendalian}

Berdasarkan hasil jawaban sebagian besar responden pada setiap satuan kerja perangkat daerah menunjukkan bahwa pimpinan instansi belum mengambil tindakan tegas atas pelanggaran prosedur atau aturan yang berlaku dalam pengelolaan keuangan 72 daerah. Hal ini disebabkan oleh belum dikomunikasikannya setiap sanksi yang berlaku kepada seluruh pegawai di lingkungan instansi tersebut sehingga pegawai pengelola keuangan belum mengetahui dan menyadari sepenuhnya konsekuensi atas pelanggaran yang dilakukannya.

\section{Penilaian Risiko}

Instansi pemerintah harus mampu mengidentifikasi secara efisien dan efektif risiko yang dapat menghambat pencapaian tujuan baik yang sumbernya berasal dari dalam maupun yang berasal dari luar instansi. Berdasarkan hasil jawaban responden, sebagaian besar berpendapat bahwa pimpinan belum memiliki rencana pengelolaan atau mengurangi risiko pelanggaran terhadap sistem dan prosedur akuntansi.

\section{Sistem Informasi Keuangan Daerah}

Hasil pengolahan data kuesioner menunjukkan bahwa skor total yang diperoleh untuk variabel sistem informasi keuangan daerah sebesar 494 dengan persentase sebesar 79,17 \% dari skala kriterium atau 3,17 (likert skala 4). Hasil perolehan skor menunjukkan bahwa sistem informasi keuangan daerah di Lingkungan Pemerintah Kabupaten Kepulauan Anambas sudah berjalan dengan baik. Hasil perolehan skor total berada pada interval baik. Hal ini menggambarkan bahwa sistem informasi keuangan daerah sangat bermanfaat dalam membantu proses penyusunan laporan keuangan. Pemanfaatan teknologi informasi berpengaruh positif dan signifikan terhadap kualitas laporan keuangan pemerintah daerah artinya bahwa semakin baik pemanfaatan teknologi informasi maka semakin baik pula kualitas Laporan Keuangan Pemerintah Daerah (Yosefrinaldi, 2008).

\section{Kualitas Laporan Keuangan Pemerintah Daerah}

Hasil pengolahan data kuesioner menunjukkan bahwa skor total yang diperoleh untuk variabel kualitas laporan keuangan pemerintah daerah sebesar 
1.324 dengan persentase sebesar 79,57\% dari skala kriterium atau 3,20 (likert skala 4). Hasil perolehan skor menunjukkan bahwa kualitas laporan keuangan pemerintah daerah di Lingkungan Pemerintah Kabupaten Kepulauan Anambas sudah berjalan dengan baik, namun seiring dengan semakin rumit dan semakin kompleksnya pengelolaan keuangan daerah yang ditandai oleh perubahan peraturan perundang-undangan diperlukan strategi untuk meningkatkan kualitas pelaporan keuangan tersebut. Kompetensi sumber daya manusia, pengendalian intern, pemanfaatan teknologi informasi dan pemahaman akuntansi menjadi faktor yang sangat menentukan terhadap kualitas pelaporan keuangan suatu pemerintah daerah (Setiawati dan Sari, 2014).

Kondisi kualitas laporan keuangan berdasarkan kondisi yang mengacu pada hasil analisis tersebut menunjukkan masih perlunya dilakukan pembenahan terhadap pengelolaan keuangan dalam rangka mempertahankan opini BPK terhadap kualitas laporan keuangan Pemerintah Kabupaten Kepulauan Anambas. Terdapat beberapa indikator yang paling dominan untuk segera dibenahi yang disajikan pada Tabel 2.
Tabel 2 Permasalahan utama peningkatan kualitas LKPD

\begin{tabular}{cllc}
\hline No. & \multicolumn{1}{c}{ Variabel } & \multicolumn{1}{c}{ Indikator } & Skor \\
\hline \multirow{2}{*}{1} & Kompetensi & Keahlian & 2,54 \\
& SDM & & 2,23 \\
& Sistem & Lingkungan & \\
2 & Pengendalian & Pengendalian & \\
& Intern & Pen & \\
\hline
\end{tabular}

Sumber : Data diolah (2017)

\section{Strategi Peningkatan Kualitas Laporan Keuangan Pemerintah}

\section{Identifikasi Faktor Kunci Eksternal dan Internal}

Berdasarkan hasil wawancara yang dilakukan dengan pimpinan Badan Keuangan Daerah dan kajian terhadap dokumen terkait, diperoleh 22 (dua puluh dua) faktor strategis yang berperan dalam peningkatan kualitas laporan keuangan Pemerintah Kabupaten Kepulauan Anambas. Langkah selanjutnya adalah memberikan kuesioner kepada informan Badan Keuangan Daerah untuk melakukan penilaian atas faktor internal dan eksternal. Hasil penilaian atas faktor internal dan eksternal menggunakan Internal Factor Evaluation (IFE) dan External Factor Evaluation (EFE) disajikan dalam Tabel 3 dan Tabel 4.

Tabel 3 Analisis IFE peningkatan kualitas laporan keuangan Pemerintah Kabupaten Kepulauan Anambas

\begin{tabular}{|c|c|c|c|c|}
\hline No. & Kekuatan & Bobot & Rating & Skor \\
\hline 1 & $\begin{array}{l}\text { Kebijakan Pemerintah Daerah dalam mendukung pengelolaan } \\
\text { keuangan }\end{array}$ & 0.117 & 4.00 & 0.467 \\
\hline 2 & Tupoksi yang jelas bagi pengelola keuangan & 0.102 & 3.33 & 0.340 \\
\hline 3 & $\begin{array}{l}\text { Ketersediaan sarana pendukung penyusunan laporan keuangan } \\
\text { yang memadai }\end{array}$ & 0.111 & 3.33 & 0.370 \\
\hline 4 & $\begin{array}{l}\text { Adanya Standar Operasional Prosedur (SOP) yang jelas dalam } \\
\text { penyusunan laporan keuangan }\end{array}$ & 0.107 & 3.33 & 0.358 \\
\hline \multirow[t]{2}{*}{5} & $\begin{array}{l}\text { Komitmen pimpinan BKD yang kuat dalam rekonsiliasi data } \\
\text { keuangan dan aset daerah }\end{array}$ & 0.098 & 3.33 & 0.327 \\
\hline & Total Kekuatan & 0.535 & & 1.862 \\
\hline
\end{tabular}




\begin{tabular}{|c|c|c|c|c|}
\hline \multicolumn{5}{|c|}{ Tabel 3 (lanjutan) } \\
\hline \multicolumn{2}{|r|}{ Kelemahan } & \multirow{2}{*}{$\frac{\text { Bobot }}{0.094}$} & \multirow{2}{*}{$\begin{array}{c}\text { Rating } \\
2.00\end{array}$} & \multirow{2}{*}{$\begin{array}{c}\text { Skor } \\
0.189\end{array}$} \\
\hline 1 & $\begin{array}{l}\text { Pelatihan dan sosialisasi keuangan daerah dari pemerintah daerah } \\
\text { kurang memadai }\end{array}$ & & & \\
\hline 2 & $\begin{array}{l}\text { Keterbatasan pagu anggaran dalam mendukung peningkatan } \\
\text { kinerja pengelola keuangan }\end{array}$ & 0.100 & 1.67 & 0.167 \\
\hline 3 & Lemahnya pengawasan internal & 0.085 & 1.67 & 0.142 \\
\hline 4 & Lemahnya kompetensi aparatur pengelola keuangan & 0.096 & 2.00 & 0.193 \\
\hline \multirow[t]{3}{*}{5} & Belum tersedianya tenaga auditor yang handal & 0.089 & 1.67 & 0.148 \\
\hline & Total Kelemahan & 0.465 & & 0.838 \\
\hline & Total & 1.000 & & 2.700 \\
\hline
\end{tabular}

Sumber : Data diolah (2017)

Hasil perhitungan Internal Factor Evaluation (IFE) menunjukkan total nilai tertimbang untuk faktor kekuatan sebesar 1,862 dan 0,838 untuk faktor kelemahan. Hal ini mengindikasikan bahwa Pemerintah Kabupaten Kepulauan Anambas berada dalam posisi internal yang kuat dan memiliki kekuatan yang lebih besar dibandingkan faktor kelemahannya. Hasil perhitungan IFE pada Tabel 3 menunjukkan bahwa kebijakan pemerintah daerah dalam mendukung pengelolaan keuangan sebagai kekuatan utama bagi Pemerintah Kabupaten Kepulauan Anambas dengan nilai tertimbang paling tinggi sebesar
0,467 yang ditunjukkan dengan nilai rating 4 . Berdasarkan perhitungan untuk faktor kelemahan, lemahnya kompetensi aparatur pengelola keuangan menjadi kelemahan bagi Pemerintah Kabupaten Kepulauan Anambas dengan nilai tertimbang sebesar 0,193. Lemahnya kompetensi pengelola keuangan Pemerintah Kabupaten Kepulauan Anambas sesuai dengan hasil yang diperoleh berdasarkan analisis rating scale pada tujuan penelitian pertama bahwa sebagian besar responden menjawab masih kurangnya pelatihan yang diselenggarakan bagi pengelola keuangan.

\section{Tabel 4 Analisis EFE peningkatan kualitas laporan keuangan Pemerintah Kabupaten} Kepulauan Anambas

\begin{tabular}{clccc}
\hline No. & \multicolumn{1}{c}{ Peluang } & Bobot & Rating & Skor \\
\hline 1 & $\begin{array}{l}\text { Peningkatan jumlah dan kualitas SDM aparatur pengelola } \\
\text { keuangan daerah melalui seleksi ASN }\end{array}$ & 0.081 & 4.00 & 0.323 \\
2 & $\begin{array}{l}\text { Kerjasama dengan lembaga BPKP dan BPK dalam review LKPD } \\
3\end{array}$ & 0.077 & 3.33 & 0.257 \\
& $\begin{array}{l}\text { Pemberian insentif/honorarium bagi pengelola keuangan dalam } \\
\text { meningkatkan kinerja } \\
\text { Tindak lanjut temuan BPK sesuai batas waktu }\end{array}$ & 0.074 & 3.67 & 0.273 \\
5 & $\begin{array}{l}\text { Peningkatan pelaksanaan pengawasan melekat oleh pimpinan } \\
\text { SKPD }\end{array}$ & 0.078 & 3.67 & 0.296 \\
6 & $\begin{array}{l}\text { Pemberian Sanksi bagi Pimpinan SKPD yang belum melakukan } \\
\text { rekonsiliasi data keuangan }\end{array}$ & 0.076 & 3.00 & 0.227 \\
& Total Peluang & 0.467 & & 1.664 \\
\hline
\end{tabular}




\begin{tabular}{llccc}
\hline \hline \multicolumn{1}{c}{ Tabel 4 (lanjutan) } & & & \\
\hline \multicolumn{1}{c}{ Ancaman } & Bobot & Rating & Skor \\
\hline 1 & $\begin{array}{l}\text { Kewajiban Implementasi PP Nomor 71 tentang SAP berbasis akrual } \\
\text { dalam penyusunan laporan keuangan }\end{array}$ & 0.095 & 1.67 & 0.158 \\
2 & $\begin{array}{l}\text { Belum adanya evaluasi rutin atas hasil pemeriksaan keuangan } \\
3\end{array}$ & 0.091 & 2.00 & 0.182 \\
4 & $\begin{array}{l}\text { Rendahnya kepatuhan terhadap peraturan perundang-undangan } \\
\text { Mutasi dan promosi jabatan terhadap aparatur pengelola keuangan }\end{array}$ & 0.082 & 3.33 & 0.274 \\
5 & $\begin{array}{l}\text { Pelayanan dari pihak Bank belum maksimal } \\
6\end{array}$ & Perubahan SOTK baru berdasarkan PP 18 Tahun 2016 & 2.00 & 0.174 \\
\hline & Total & 0.090 & 1.67 & 0.149 \\
\hline & & 0.088 & 3.67 & 0.324 \\
\hline
\end{tabular}

Sumber : Data diolah (2017)

Total nilai tertimbang atau skor untuk faktor eksternal yang menjadi peluang adalah sebesar 1,664 sedangkan untuk ancaman memiliki skor atau nilai tertimbang sebesar 1,261. Hasil perhitungan EFE pada Tabel 4 menunjukkan bahwa Pemerintah Kabupaten Kepulauan Anambas memiliki faktor peluang yang lebih besar daripada faktor yang menjadi ancaman. Berdasarkan hasil pengolahan kuesioner menunjukkan bahwa faktor peningkatan jumlah dan kualitas SDM aparatur pengelola keuangan daerah melalui seleksi ASN merupakan peluang utama dengan skor tertinggi yaitu 0,323 . Faktor ancaman yaitu perubahan Susunan Organisasi dan Tata Kerja (SOTK) baru berdasarkan Peraturan Pemerintah Nomor 18 Tahun 2016 tentang perangkat daerah merupakan ancaman utama dengan nilai tertimbang sebesar 0,324. Terjadinya perubahan terhadap organisasi perangkat daerah (OPD) di Lingkungan Pemerintah Kabupaten Kepulauan Anambas semakin mempersulit penyusunan laporan keuangan dan pendataan aset daerah dikarenakan membutuhkan penyesuaian kembali terhadap penyajian laporan keuangan.

\section{Perumusan Alternatif Strategi Melalui Analisis SWOT}

Dalam menentukan alternatif strategi dan keterkaitan antar strategi, maka perlu dilakukan interaksi kombinasi strategi internal maupun eksternal. Adapun perumusan strategi disusun berdasarkan faktor internal serta faktor eksternal ke dalam matriks SWOT seperti disajikan pada Tabel 5.

\section{Perumusan Strategi Prioritas melalui Quantitative Strategic Planning Matrix (QSPM)}

Penggunaan QSPM bertujuan untuk memperoleh prioritas strategi terbaik yang paling menarik untuk diimplementasikan sesuai dengan arah dan kebijakan Pemerintah Kabupaten Kepulauan Anambas dalam hal pengelolaan keuangan daerah. Penentuan prioritas strategi terbaik dilakukan dengan cara menentukan rating atau tingkat ketertarikan relatif dari strategi-strategi yang telah dipilih. Nilai skor daya tarik tertinggi menandakan strategi yang paling layak untuk diimplementasikan dengan memperhatikan seluruh faktor internal dan eksternal (David, 2015). Hasil perumusan strategi prioritas menggunakan QSPM memprioritaskan pada strategi ketiga yaitu "Meningkatkan kualitas SDM pengelola keuangan daerah dalam penyusunan laporan keuangan." Dengan skor TAS sebesar 6,549. 


\section{Tabel 5 Matriks SWOT dan Alternatif Strategi Peningkatan Kualitas Laporan Keuangan}

\begin{tabular}{|c|c|c|}
\hline \multirow{2}{*}{ IFE } & S - KEKUATAN & W - KELEMAHAN \\
\hline & $\begin{array}{l}\text { 1. Kebijakan Pemda dalam } \\
\text { mendukung pengelolaan } \\
\text { keuangan } \\
\text { 2. Tupoksi yang jelas bagi } \\
\text { pengelola keuangan } \\
\text { 3. Ketersediaan sarana pendukung } \\
\text { penyusunan laporan keuangan } \\
\text { yang memadai } \\
\text { 4. Adanya SOP yang jelas dalam } \\
\text { penyusunan laporan keuangan } \\
\text { 5. Komitmen pimpinan BKD } \\
\text { yang kuat dalam rekonsiliasi } \\
\text { data keuangan }\end{array}$ & $\begin{array}{l}\text { 1. Pelatihan dan sosialisasi } \\
\text { keuangan daerah kurang } \\
\text { memadai } \\
\text { 2. Keterbatasan pagu } \\
\text { anggaran dalam } \\
\text { mendukung peningkatan } \\
\text { kinerja pengelola } \\
\text { keuangan } \\
\text { 3. Lemahnya pengawasan } \\
\text { internal } \\
\text { 4. Lemahnya kompetensi } \\
\text { aparatur pengelola } \\
\text { keuangan } \\
\text { 5elum tersedianya tenaga } \\
\text { auditor yang handal }\end{array}$ \\
\hline \multicolumn{3}{|l|}{ O - PELUANG } \\
\hline $\begin{array}{l}\text { 1. Peningkatan jumlah dan kualitas } \\
\text { SDM aparatur pengelola } \\
\text { keuangan daerah melalui seleksi } \\
\text { ASN } \\
\text { 2. Kerjasama dengan lembaga } \\
\text { BPKP dan BPK dalam review } \\
\text { LKPD } \\
\text { 3. Pemberian insentif/honorarium } \\
\text { bagi pengelola keuangan dalam } \\
\text { meningkatkan kinerja } \\
\text { 4. Tindak lanjut temuan BPK } \\
\text { sesuai batas waktu } \\
\text { 5. Peningkatan pelaksanaan } \\
\text { pengawasan melekat oleh } \\
\text { pimpinan SKPD } \\
\text { 6. Pemberian Sanksi bagi Pimpinan } \\
\text { SKPD yang belum melakukan } \\
\text { rekonsiliasi data keuangan. }\end{array}$ & \begin{tabular}{l}
\multicolumn{1}{c}{ STRATEGI S - O } \\
1. Melakukan peningkatan kinerja \\
pengelola keuangan dalam \\
rekonsiliasi data keuangan \\
dalam mendukung penyampaian \\
laporan keuangan tepat waktu \\
(S2, S3, S4, S5, O3,O4) \\
2. Menerapkan sanksi yang tegas \\
dalam mendukung komitmen \\
pimpinan BKD dalam \\
melakukan rekonsiliasi data \\
keuangan dan aset daerah. (S5, \\
O5,O6) \\
3. Meningkatkan kualitas SDM \\
pengelola keuangan daerah \\
dalam penyusunan laporan \\
keuangan (S1, S3, O1, O2, O3)
\end{tabular} & $\begin{array}{l}\text { STRATEGI W - O } \\
\text { 1. Meningkatkan kompetensi } \\
\text { auditor internal melalui } \\
\text { kerjasama dengan pihak } \\
\text { eksternal (W1, W3, W5, } \\
\text { O2, O4, O5) }\end{array}$ \\
\hline \multicolumn{3}{|l|}{ T - ANCAMAN } \\
\hline $\begin{array}{l}\text { 1. Kewajiban Implementasi PP } \\
\text { Nomor } 71 \text { tentang SAP berbasis } \\
\text { akrual dalam penyusunan } \\
\text { laporan keuangan } \\
\text { 2. Belum adanya evaluasi rutin atas } \\
\text { hasil pemeriksaan keuangan } \\
\text { 3. Rendahnya kepatuhan terhadap } \\
\text { peraturan perundang-undangan } \\
\text { 4. Mutasi dan promosi jabatan } \\
\text { terhadap aparatur pengelola } \\
\text { keuangan daerah } \\
\text { 5. Pelayanan dari pihak Bank } \\
\text { belum maksimal } \\
\text { 6. Perubahan SOTK baru } \\
\text { berdasarkan PP } 18 \text { Tahun } 2016\end{array}$ & $\begin{array}{l}\text { STRATEGI S - T } \\
\text { 1. Meningkatkan evaluasi rutin } \\
\text { dan pengawasan internal yang } \\
\text { efektif untuk meningkatkan } \\
\text { kepatuhan terhadap peraturan } \\
\text { perundang-undangan } \\
\text { pengelolaan keuangan daerah } \\
\text { (S1, S5, T1, T2,T3) } \\
\text { 2. Melakukan perbaikan terhadap } \\
\text { tupoksi dan SOP dalam } \\
\text { mendukung kewajiban } \\
\text { implementasi SAP berbasis } \\
\text { akrual (S2,S4, T1, T4, T6) } \\
\text { 3. Meningkatkan pelayanan pihak } \\
\text { bank secara maksimal melalui } \\
\text { kebijakan pemerintah daerah } \\
\text { dan sarana pendukung yang } \\
\text { memadai (S1, S3, T5) }\end{array}$ & $\begin{array}{l}\text { STRATEGI W - T } \\
\text { 1. Mengurangi perpindahan } \\
\text { atau mutasi aparatur } \\
\text { pengelola keuangan dengan } \\
\text { mengalokasikan anggaran } \\
\text { dalam peningkatan kinerja } \\
\text { pengelola keuangan. (W2, } \\
\text { W3, W4, T4, T6) }\end{array}$ \\
\hline
\end{tabular}

Sumber : Data diolah (2017)

Hasil perumusan strategi berdasarkan penilaian informan ahli ini sesuai dengan hasil analisis tujuan pertama bahwa masih terdapat kelemahan 
dalam unsur unsur sistem pengendalian intern yang meliputi lingkungan pengendalian dan penilaian resiko. Lemahnya sistem pengendalian intern ini diperkuat oleh temuan Badan Pemeriksa Keuangan pada LHP Pemerintah Kabupaten Kepulauan Anambas tahun 2015 nomor 03.C/LHP/XVIII.TJP/5/2016 yang menyatakan bahwa sistem pengendalian intern Pemerintah Kabupaten Kepulauan Anambas belum memadai sehingga mengakibatkan rendahnya kepatuhan terhadap peraturan perundang-undangan. Rendahnya kepatuhan terhadap peraturan perundangundangan diakibatkan kurangnya kompetensi SDM pengelola keuangan dalam memahami peraturan terkait dengan pengelolaan keuangan daerah yang diperkuat oleh hasil analisis data pada variabel kompetensi SDM. Penentuan prioritas strategi dari beberapa strategi yang dihasilkan dalam matriks SWOT selanjutnya akan dilakukan menggunakan alat analisis Quantitative Strategic Planning Matrix (QSPM).

Hal ini mengindikasikan bahwa Pemerintah Kabupaten Kepulauan Anambas perlu melakukan percepatan dalam meningkatkan kualitas SDM pengelola keuangan termasuk dalam hal kompetensinya serta keahliannya sehingga diharapkan akan terjadi peningkatan dalam pengelolaan keuangan dan kualitas pelaporan keuangan kedepannya. Hasil analisis QSPM disajikan pada Tabel 6 .

Tabel 6 Hasil Analisis QSPM

\begin{tabular}{|c|c|c|c|}
\hline No. & Strategi & TAS & Peringkat \\
\hline 1 & $\begin{array}{l}\text { Melakukan peningkatan kinerja pengelola keuangan dalam } \\
\text { rekonsiliasi data keuangan dalam mendukung penyampaian } \\
\text { laporan keuangan tepat waktu }\end{array}$ & 5.823 & 6 \\
\hline 2 & $\begin{array}{l}\text { Menerapkan sanksi yang tegas dalam mendukung komitmen } \\
\text { pimpinan BKD dalam melakukan rekonsiliasi data keuangan } \\
\text { dan aset daerah }\end{array}$ & 6.010 & 2 \\
\hline 3 & $\begin{array}{l}\text { Meningkatkan kualitas SDM pengelola keuangan daerah dalam } \\
\text { penyusunan laporan keuangan }\end{array}$ & 6.549 & 1 \\
\hline 4 & $\begin{array}{l}\text { Meningkatkan kompetensi auditor internal melalui kerjasama } \\
\text { dengan pihak eksternal }\end{array}$ & 5.682 & 8 \\
\hline 5 & $\begin{array}{l}\text { Meningkatkan evaluasi rutin dan pengawasan internal yang } \\
\text { efektif untuk meningkatkan kepatuhan terhadap peraturan } \\
\text { perundang-undangan pengelolaan keuangan daerah }\end{array}$ & 5.842 & 5 \\
\hline 6 & $\begin{array}{l}\text { Melakukan perbaikan terhadap tupoksi dan SOP dalam } \\
\text { mendukung kewajiban implementasi SAP berbasis akrual }\end{array}$ & 5.909 & 4 \\
\hline 7 & $\begin{array}{l}\text { Meningkatkan pelayanan pihak bank secara maksimal melalui } \\
\text { kebijakan pemerintah daerah dan sarana pendukung yang } \\
\text { memadai }\end{array}$ & 5.985 & 3 \\
\hline 8 & $\begin{array}{l}\text { Mengurangi perpindahan atau mutasi aparatur pengelola } \\
\text { keuangan dengan mengalokasikan anggaran dalam peningkatan } \\
\text { kinerja pengelola keuangan }\end{array}$ & 5.786 & 7 \\
\hline
\end{tabular}

Sumber: Data diolah (2017) 


\section{Perancangan program}

Berdasarkan strategi utama peningkatan kualitas laporan keuangan yang dipilih berdasarkan hasil analisis QSPM maka selanjutnya perlu dilakukan perancangan program dalam rangka pelaksanaan strategi prioritas tersebut. Dalam pelaksanaan strategi diperlukan acuan sehingga pelaksanaannya menjadi lebih mudah untuk dilakukan. Perlu disusun kebijakan operasional sehingga dapat menjadi arahan dalam melaksanakan program dan kegiatan dalam peningkatan kualitas laporan keuangan pada Pemerintah Kabupaten Kepulauan Anambas. perancangan program dan kegiatan disajikan dalam Tabel 7.

Tabel 7 Implementasi strategi peningkatan kualitas laporan keuangan Pemerintah Kabupaten Kepulauan Anambas

\begin{tabular}{|c|c|c|c|c|c|}
\hline Strategi & Program & Kegiatan & Output & $\begin{array}{c}\text { Penanggung } \\
\text { Jawab }\end{array}$ & $\begin{array}{c}\text { Waktu } \\
\text { Pelaksanaa } \\
\text { n } \\
\end{array}$ \\
\hline \multirow[t]{4}{*}{$\begin{array}{l}\text { Meningkatka } \\
\text { n kualitas } \\
\text { SDM } \\
\text { pengelola } \\
\text { keuangan } \\
\text { daerah dalam } \\
\text { penyusunan } \\
\text { laporan } \\
\text { keuangan }\end{array}$} & $\begin{array}{l}\text { 1. Program } \\
\text { Pembinaan } \\
\text { dan } \\
\text { Pengembanga } \\
\text { n Aparatur }\end{array}$ & $\begin{array}{l}\text { 1. Rekruitmen } \\
\text { SDM } \\
\text { pengelola } \\
\text { keuangan } \\
\text { berkualitas } \\
\text { melalui seleksi } \\
\text { ASN }\end{array}$ & $\begin{array}{l}\text { Tersedianya } \\
\text { formasi } \\
\text { pengelola } \\
\text { keuangan } \\
\text { sesuai dengan } \\
\text { kompetensiny } \\
\text { a }\end{array}$ & $\begin{array}{l}\text { Badan } \\
\text { Kepegawaian } \\
\text { dan } \\
\text { Pengembanga } \\
\text { n Sumber } \\
\text { Daya } \\
\text { Manusia }\end{array}$ & $2018-2019$ \\
\hline & $\begin{array}{l}\text { 2. Peningkatan } \\
\text { Pembinaan } \\
\text { dan } \\
\text { Pengembanga } \\
\text { n Aparatur }\end{array}$ & $\begin{array}{l}\text { 1. Bimbingan } \\
\text { teknis } \\
\text { penyelenggaraa } \\
\text { n Sistem } \\
\text { Pengendalian } \\
\text { Intern }\end{array}$ & $\begin{array}{l}\text { Meningkatny } \\
\text { a } \\
\text { pemahaman, } \\
\text { pengetahuan } \\
\text { dan } \\
\text { kompetensi } \\
\text { Pimpinan } \\
\text { SKPD } \\
\text { terhadap } \\
\text { pentingnya } \\
\text { Sistem } \\
\text { Pengendalian } \\
\text { Intern }\end{array}$ & $\begin{array}{l}\text { Inspektorat } \\
\text { Daerah }\end{array}$ & $2019-2020$ \\
\hline & & $\begin{array}{l}\text { 2. Bimbingan } \\
\text { teknis } \\
\text { pengelolaan } \\
\text { aset daerah } \\
\text { bagi pengurus } \\
\text { barang daerah }\end{array}$ & $\begin{array}{l}\text { Meningkatny } \\
\text { a pemahaman } \\
\text { pengurus } \\
\text { barang milik } \\
\text { daerah dalam } \\
\text { penatausahaa } \\
\text { n barang } \\
\text { milik daerah }\end{array}$ & $\begin{array}{l}\text { Badan } \\
\text { Keuangan } \\
\text { Daerah }\end{array}$ & $2018-2021$ \\
\hline & & $\begin{array}{l}\text { 3. Bimbingan } \\
\text { teknis sistem } \\
\text { akuntansi } \\
\text { berbasis akrual }\end{array}$ & $\begin{array}{l}\text { Meningkatny } \\
\text { a pemahaman } \\
\text { pengelola } \\
\text { keuangan } \\
\text { terhadap } \\
\text { akuntansi } \\
\text { berbasis } \\
\text { akrual }\end{array}$ & $\begin{array}{l}\text { Badan } \\
\text { Keuangan } \\
\text { Daerah }\end{array}$ & $2018-2020$ \\
\hline
\end{tabular}

Sumber: Data diolah (2017) 
Dalam rangka mempercepat proses pemahaman kepada pengelola keuangan tentang pentingnya laporan keuangan yang sesuai dengan standar dan dapat dipercaya serta berguna bagi pengambilan keputusan adalah dengan melakukan bimbingan teknis dan sosialisasi tentang implementasi pengelolaan keuangan yang baik kepada seluruh pengelola keuangan mulai dari pimpinan dan pejabat struktural pemerintah daerah terutama Bendaharawan dan Pejabat Pelaksana Teknis Kegiatan (PPTK) Satuan Kerja Perangkat Daerah (SKPD), Pejabat Penatausahaan Keuangan SKPD (PPKSKPD), sampai kepada para Kepala SKPD selaku Pengguna Anggaran (PA)/Pengguna Barang (PB) dan Kuasa Pengguna Anggaran (KPA)/Kuasa Pengguna Barang (KPB).

Berdasarkan hasil penelitian, bimbingan teknis ataupun diklat yang menjadi prioritas utama untuk dilaksanakan adalah:

1. Bimbingan Teknis Penyelenggaraan Sistem Pengendalian Intern

Berdasarkan hasil penelitian pada analisis rating scale diperoleh hasil bahwa sistem pengendalian intern pada Pemerintah Kabupaten Kepulauan Anambas belum memadai. Efektivitas pengendalian intern pada setiap satuan kerja perangkat daerah sangat dipengaruhi oleh kompetensi sumber daya manusia serta pemahaman pimpinan terhadap sistem pengendalian itu sendiri. Efektifitas pengendalian intern menjadi salah satu kriteria penilaian dalam opini Badan Pemeriksa Keuangan. Melalui pelaksanaan sistem pengendalian intern yang baik, maka instansi pemerintah dapat mencapai tujuannya secara efisien dan efektif, melaporkan pengelolaan keuangan negara secara andal, mengamankan aset negara, dan mendorong ketaatan terhadap peraturan perundang-undangan dan akan meningkatkan kualitas pelaporan keuangan. Perlu dibangun pemahaman bagi pimpinan SKPD melalui pelatihan sistem pengendalian intern sehingga seluruh unsur pengendalian dapat dilaksanakan dengan baik.

2. Bimbingan Teknis Pengelolaan Aset Daerah

Pengelolaan keuangan daerah telah mengalami penyesuaian dengan terbitnya Permendagri Nomor 64 Tahun 2013 tentang Penerapan Standar Akuntansi Pemerintah berbasis Akrual, begitu pun halnya dalam pengelolaan barang daerah juga harus menyesuaikan dengan peraturan tersebut yang mulai memperhitungkan adanya penyusutan serta setiap pemerintah daerah dalam melakukan pengelolaan barang milik daerah juga harus mengikuti ketentuan ataupun petunjuk teknis dalam Peraturan Menteri Dalam Negeri Nomor 19 Tahun 2016 tentang Pengelolaan Barang Milik Daerah, sehingga perlu dilakukan peningkatan kompetensi SDM pengelola barang milik daerah. Berdasarkan hasil wawancara dengan Kepala Bidang Aset Badan Keuangan Daerah diperoleh informasi bahwa selama ini diklat mengenai pengelolaan aset daerah belum pernah dilakukan di Kabupaten Kepulauan Anambas. Melalui pelaksanaan bimbingan teknis ini diharapkan dapat meningkatkan pemahaman pengelola barang milik daerah mulai dari perencanaan sampai dengan penghapusan dan terciptanya tata kelola barang milik daerah yang baik dan berbasis akrual.

3. Bimbingan Teknis Sistem Akuntansi berbasis akrual

Salah satu bagian dari manajemen pengelolaan keuangan daerah yang substansial adalah standar akuntansi pemerintah berbasis akrual. Bimbingan teknis perlu dilakukan dengan harapan pengelola keuangan mengetahui dan memahami kebijakan akuntansi berbasis akrual serta penggunaan SIKD. Setelah dilakukan pelatihan selanjutnya perlu dilaksanakan kegiatan Pendampingan 
Penyusunan Laporan Keuangan SKPD untuk mendampingi SKPD dalam menyusun penyajian kembali (restatement) laporan keuangan SKPD. Kegiatan Fasilitasi Pendampingan khususnya terhadap penggunaan SIKD bertujuan membantu pengelola keuangan bila menemui hambatan maupun kesulitan dalam proses penatausahaan keuangan dengan menggunakan SIKD termasuk pada saat penyesuaian data SIKD bila terdapat updating berkala.

\section{SIMPULAN}

1. Berdasarkan analisis rating scale dapat disimpulkan bahwa masih terdapat kelemahan dalam pelaksanaan sistem pengendalian intern khususnya pada lingkungan pengendalian dimana efektivitas sistem pengendalian intern erat kaitannya dengan kompetensi sumber daya manusia khususnya pimpinan instansi pemerintah.

2. Berdasarkan hasil analisis SWOT yang dilakukan terhadap faktor internal menunjukkan bahwa Pemerintah Kabupaten Kepulauan Anambas memiliki kekuatan yang lebih besar dibandingkan faktor kelemahannya. Kebijakan pemerintah daerah dalam mendukung pengelolaan keuangan sebagai kekuatan utama yang dimiliki dan lemahnya kompetensi pengelola keuangan menjadi kelemahan terbesar khususnya dalam upaya peningkatan kualitas laporan keuangan. Lemahnya kompetensi SDM pengelola keuangan disebabkan masih kurangnya pelatihan maupun sosialisasi yang dilakukan sementara berbagai aturan dan kebijakan pengelolaan keuangan daerah terus diperbaharui sehingga kurangnya pemahaman pengelola keuangan akan berdampak terhadap peningkatan kualitas laporan keuangan yang dihasilkan.

3. Strategi yang harus dilaksanakan terkait dengan peningkatan kualitas laporan keuangan Pemerintah Kabupaten Kepulauan Anambas adalah dengan cara meningkatkan kualitas SDM pengelola keuangan daerah dalam penyusunan laporan keuangan. Dengan semakin kompleks dan berkembangnya peraturan yang berlaku dalam pengelolaan keuangan daerah, maka pengelola keuangan dituntut untuk memahami aturan yang ada. Pelatihan dan sosialisasi yang diperlukan meliputi pemahaman terhadap standar akuntansi pemerintah berbasis akrual, pemahaman mengenai pengelolaan aset daerah dan meningkatkan pemahaman pimpinan SKPD dalam hal sistem pengendalian intern.

\section{SARAN}

1. Melakukan pelatihan dan sosialisasi khususnya dalam meningkatkan kompetensi pengelola keuangan secara berkelanjutan dan terpadu.

2. Melaksanakan strategi peningkatan kualitas laporan keuangan sesuai dengan hasil yang telah dirumuskan dalam penelitian ini.

3. Melakukan pembinaan maupun sosialisasi bagi pimpinan instansi SKPD mengenai pemahaman terhadap sistem pengendalian intern yang merupakan salah satu penilaian penting dalam opini BPK.

\section{DAFTAR PUSTAKA}

[BPKRI] Badan Pemeriksa Keuangan RI Perwakilan Provinsi Kepri. 2015. Laporan Hasil Pemeriksaan Provinsi Kepulauan Riau. Batam (ID): BPK.

David FR. 2015. Strategic Management: Concepts and Cases. 15th Ed. Essex (GB): Pearson Education Limited.

Eriva CY, Islahuddin, Darwanis. 2013. Pengaruh tingkat pendidikan, pelatihan, masa kerja dan jabatan terhadap pemahaman laporan keuangan daerah (studi pada Pemerintah Aceh). Jurnal 
akuntansi Pascasarjana Universitas Syiah Kuala. 1(2): 1-14.

[KEMENDAGRI] Kementerian Dalam Negeri RI. 2006. Peraturan Menteri Dalam Negeri Nomor 13 tahun 2006 tentang tentang Pedoman Pengelolaan Keuangan Daerah. Jakarta (ID) : Kemendagri.

[KEMENDAGRI] Kementerian Dalam Negeri RI. 2013. Peraturan Menteri Dalam Negeri Nomor 64 tahun 2013 tentang Penerapan Standar Akuntansi Berbasis Akrual pada Pemerintah Daerah. Jakarta (ID) : Kemendagri.

[KEMENDAGRI] Kementerian Dalam Negeri RI. 2016. Peraturan Menteri Dalam Negeri Nomor 19 tahun 2016 tentang tentang Pedoman Pengelolaan Barang Milik Daerah. Jakarta (ID) : Kemendagri.

Kinnear, T. C. dan Taylor, J. R. 1991. Riset Pemasaran. Terjemahan. Jilid I. Erlangga, Jakarta.

Pemerintah Republik Indonesia. 2010. PP Nomor 71 Tahun 2010 tentang Standar Akuntansi Pemerintah. Jakarta (ID): Sekretariat Negara.

Riduwan. 2010. Skala Pengukuran Variabel-variabel Penelitian. Bandung (ID): Alfabeta.
Syarifudin A. 2014. Pengaruh kompetensi SDM dan peran audit intern terhadap kualitas laporan keuangan pemerintah daerah dengan variabel intervening sistem pengendalian internal pemerintah (studi empiris pada Pemkab Kebumen). Jurnal Fokus Bisnis. 14(2): 26-44.

Setiawati E, Sari SP. 2014. Kualitas pelaporan keuangan pemerintah daerah ditinjau dari sumber daya manusia, pengendalian intern, pemanfaatan teknologi informasi dan pemahaman akuntansi (studi empiris pada Pemerintah Kabupaten dan Kota di wilayah Eks Karesidenan Surakarta). Seminar Nasional FEB UMS.

Yosefrinaldi.2008. Pengaruh Kapasitas intelektual sumber daya manusia dan Pemanfaatan Tekhnologi Informasi Terhadap Kualitas Laporan Keuangan Pemerintah Daerah dengan Variabel Intervening Sistem Pengendalian Intern Pemerintah.Jurnal Akuntansi, Universitas Negeri Padang.[Internet]. [diunduh pada 2016 Jun 15]. Tersedia pada: http://ejournal.unp.ac.id/students/i ndex.php/akt/issue/view/120. 